\title{
Metode Enterprise Architecture Planning Untuk Merencanakan Sistem Informasi Manajemen Anggaran Perguruan Tinggi Swasta
}

\author{
Anton Wahyu Nugroho ${ }^{1)}$; Setiyowati ${ }^{2)}$; Andriani Kusumaningrum ${ }^{3)}$; \\ 1) Sistem Informasi-Sarjana, STMIK Sinar Nusantara Surakarta \\ ${ }^{2)}$ Sistem Informasi Akuntansi-Diploma III, STMIK Sinar Nusantara Surakarta \\ 3) Sistem Informasi-Diploma III, STMIK Sinar Nusantara Surakarta \\ 1) $\underline{\text { antonwnugroho@gmail.com; }}{ }^{2)}$ andriani@ sinus.ac.id; ${ }^{3)}$ setiyowati@sinus.ac.id
}

\begin{abstract}
The success of higher education can be seen from the performance of education, research and community service, and university governance. The use of information technology is very influential in organizational performance. Budget management and expenditure are some of the important business processes in a university involving several work units so that integration system is needed. The purpose of this study is to plan an Enterprise Architecture budget and information system of expenditure management that is integrated with systems in other work units. An Enterprise Architecture Planning (EAP) is a methodology for making enterprise architecture planningby focusing on data management architecture, application creation architecture, and technology architecture. Those will be used as well as the implementation of architecture to support the achievement of organizational goals, namely integration system. The results of this study are Blue Print of Architecture Enterprise budget and expenditure management information systems in Higher Education. This Blue Print of Enterprise Architecture information system includes several business processes, namely business processes, budget management, payroll, asset management, HR management, and attendance. This compiled architecture is still found gap. For example, there are still entities that must be added (add), retained (replaced), replaced (removed) and removed (remove), with details of 17 Added entities, 1 Retained entity, 14 Replaced entities, and 0 Removed entity. In conclusion, the total gap is 32 entities.
\end{abstract}

Keywords : Blueprint, Information Systems, Budgeting, EAP

\section{PENDAHULUAN}

Pendidikan Tinggi mencakup program diploma, program sarjana, program magister, program doktor, dan program profesi, serta program spesialis. Perguruan tinggi merupakan satuan pendidikan yang menyelenggarakan pendidikan tinggi seperti yang disebutkan dalam UU No 12 Tahun 2012 tentang Pendidikan Tinggi. Perguruan tinggi di Indonesia berdasarkan data Buku Statistik Pendidikan Tinggi 2017, di lingkungan Kemenristekdikti tercatat sebanyak 3.276 perguruan tinggi terdiri dari 122 Perguruan Tinggi Negeri dan 3.154 Perguruan Tinggi Swasta (Kementerian Riset, 2018). Sebagai organisasi yang memiliki visi dan misi, perguruan tinggi selalu berusaha mewujudkan visi misinya untuk mampu bersaing dengan perguruan tinggi lain. Keberhasilan perguruan tinggi dilihat kinerja pendidikan, penelitian dan pengabdian kepada masyarakat. Faktor keberhasilan dan persaingan antara perguruan tinggi juga berdasarkan aspek internal maupun eksternal. Salah satunya adalah faktor tata kelola perguruan tinggi dalam bidang teknologi informasi. Pemanfaatan teknologi informasi sendiri akan sangat berpengaruh terhadap berjalannya organisasi.

Pengelolaan anggaran dan belanja di Perguruan Tinggi merupakan proses bisnis yang sangat penting. Kompleksitas dalam pengelolaan anggaran dan belanja yang melibatkan banyak unit dengan sistem informasi yang berbeda-beda mengakibatkan pemrosesan data dilakukan berulang. Perguruan Tinggi dalam pengelolaan anggaran dan belanja 
melibatkan unit lain seperti Unit Keuangan untuk proses penggajian, serta unit lain seperti pada proses inventarisasi asset, unit-unit tersebut belum terintegrasi sehingga dibutuhkan koordinasi dan waktu yang lama didalam pengambilan keputusan. Untuk membantu dalam pengambilan keputusan tersebut dibutuhkan sebuah sistem informasi yang terintegrasi. Agar kebutuhan sistem dapat terakomodir dengan baik, maka dibutuhkan sebuah Blueprint sistem informasi manajemen anggaran dan belanja.

Perencanaan Arsitektur Enterprise dengan menggunakan Metode EAP yang telah dilakukan pada Perguruan Tinggi Swasta di Surakarta telah dilakukan, adapun integrasi sistem fokus pada Pembelajaran, Penelitian dan Pengabdian pada Masyarakat, sedangkan untuk integrasi sistem terkait dengan Unit Keuangan, Unit Kerumahtanggaan belum dilakukan. (A. P. Kurniawan \& Chazar, 2015)

Perencanaan arsitektur enterprise teknologi informasi manajemen anggaran dan belanja menggunakan metode Enterprise Architecture Planning (EAP). Enterprise Architecture Planning (EAP) merupakan suatu metodologi untuk membuat perencanaan arsitektur enterprise fokus pada arsitektur data, arsitektur aplikasi serta arsitektur teknologi serta implementasi arsitektur untuk mendukung tercapainya tujuan organisasi yaitu integrasi sistem. Arsitektur Enterprise akan memberikan gambaran kebutuhan aplikasi serta kandidat aplikasi yang cocok untuk dikembangkan, dan arsitektur teknologi yang akan menjelaskan kebutuhan teknologi serta platform apa saja yang sesuai dan juga sebuah topologi jaringan.(Surendro et al., 2007)

Tujuan penelitian ini adalah membuat perencanaan sistem informasi manajemen anggaran dan belanja yang terintegrasi dengan unit-unit yang terlibat di Perguruan Tinggi.

\section{TINJAUAN PUSTAKA}

\subsection{Penelitian Terkait}

Penelitian tentang penerapan metode Enterprise Architecture Planning (EAP). telah dilakukan oleh Ady Purna Kurniawan, Chalifa Chazar dalam jurnal berjudul Perencanaan Cetak Biru Sistem Informasi Terintegrasi Berbasis E2AF dan Metodologi EAP (Studi Kasus Universitas Muhammadiyah Surakarta) berdasarkan penelitian yang dilakukan, diperoleh hasil sebuah blueprint sistem informasi yaitu arsitektur data, arsitektur aplikasi dan arsitektur teknologi dan implementasinya. Komponen yang ada di EAP hanya mengisi 4 level pada tahapan E2AF, yaitu contextual level (Why), conceptual level (What), physical level (With What), dan transformation level (When) untuk elemen sistem informasi (A. P. Kurniawan \& Chazar, 2015)

Menurut penelitian oleh Nia Ambarsari dan Nurvita Setyoutami tahun 2014 diperoleh sebuah blueprint sistem informasi yang memiliki 18 entitas data serta 7 kandidat aplikasi yang dapat dikembangkan guna membantu proses bisnis yang ada di sekolah (Ambarsari \& Setyoutami, 2014). Kemudian menurut penelitian oleh Yusup Miftahuddin, Muhammad Ichwan dan Mira Musrini tahun 2013 bahwa blueprint sistem akademik memiliki aspek penting meliputi proses bisnis sistem, pihak yang terlibat pada sistem, data yang dibutuhkan oleh sistem dan matrikulasi sistem. 15 pihak yang terlibat pada sistem dan 6 matrikulasi: proses vs bisnis, proses vs organisasi, sistem vs organisasi dan proses vs kelas data. Metodologi EAP dapat digunakan untuk pengembangan sistem akademik di ITENAS (Miftahuddin et al., 2013)

Berdasarkan penelitian oleh Bobi Kurniawan, Enterprise Architecture Planning untuk Sistem Informasi Perguruan Tinggi Swasta dengann Zachman Framework dijelaskan bahwa EAP merupakan bagian dari Zachman Framework. Pada tahapan EAP meliputi Inisiasi Perencanaan (Planning Initiation), mengidentifikasi dan mendefinisikan fungsi bisnis, arsitektur data yang terdiri dari kandidat entitas data, entitas set, atribut dan 
relasinya, asritektur aplikasi, arsitektur teknologi serta rencana implementasi. (B. Kurniawan, 2011)

Penelitian yang dilakukan oleh Nyoman Ayu Nila Dewi, Benyamin L.Sinaga, Eduard Rusdianto tentang penggunaan Enterprise Architecture Planning untuk Perencanaan Layanan Sistem Informasi diperoleh tahapan 1) Rantai nilai (Value Chain), 2) Fungsi Bisnis, model bisnis, 3) Arsitektur sistem dan teknologi saat ini, 4) Perencanaan arsitektur data, 5) Perencanaan arsitektur aplikasi, arsitektur teknologi, dan 6). Rencana implementasi. (Ayu et al., 2013)

\subsection{Enterprise Architecture Planning}

Enterprise Architecture Planning (EAP) merupakan proses pendefinisian arsitektur dalam penggunaan informasi untuk mendukung bisnis dan rencana untuk mengimplementasikan arsitektur tersebut. EAP memiliki 7 (tujuh) komponen utama yang merupakan tahapan dalam menentukan serta merencanakan implementasi arsitektur sistem informasi.(Bernard, 2009) Tujuh komponen utama tersebut dikelompokkan ke dalam 4 (empat) lapisan. Lapisan terdiri dari :

1. Inisialisasi perencanaan

Inisiasi perencanaan adalah tahap pendefinisian awal yang mencakup nilai-nilai maupun komponen yang terkandung dalam visi misi. Pendefinisian tersebut sesuai dengan tujuan maupun aturan aturan yang ada.

2. Tinjauan kondisi enterprise saat ini

Tahapan ini memberikan landasan dalam melaksanakan atau melakukan perencanaan sistem dan teknologi serta migrasi ke depannya. Yang mencakup dua tahap yaitu :

a. Pemodelan proses bisnis

b. Pendefinisian teknologi dan sistem saat ini

3. Tinjauan rencana enterprise di masa depan.

4. Tahapan ini mendefinisikan rancangan sistem dan teknologi yang dibutuhkan di masa depan, rancangan tersebut meliputi:

\section{a. Arsitektur Data}

Arsitektur data menjelaskan tentang entitas yang terlibat serta relasi antar entitasnya. Identifikasi dan definisi jenis data utama yang diperlukan enterprise untuk mendukung fungsi bisnis yang didefinisikan pada tahap pemodelan bisnis kemudian merelasikan entitas data tersebut dengan fungsi bisnis enterprise.

Tahapan dari arsitektur data :

1. Tahapan Membuat daftar kandidat entitas data, yang bertujuan untuk mengidentifikasikan semua entitas data yang dibutuhkan enterprise, atau dengan melihat kebutuhan data di masing-masing business process yang telah didefinisikan pada tahapan permodelan bisnis.

2. Tahapan Membuat diagram hubungan antar entitas data. Masing-masing entitas data saling mendukung area fungsi bisnis lain, serta memiliki ketergantungan dengan entitas data lainnya. Integrasi antar proses bisnis yang didefiniskan dalam entitas relasi data akan mendapatkan keterkaitan entitas pada enterprise. Pemodelan digambarkan dengan Entity Relationship Diagram (ERD).

3. Tahapan definisi relasi antar entitas data digambarkan dalam matriks yang mendeskripsikan entitas data dalam proses bisnis.

\section{b. Arsitektur Aplikasi}

Arsitektur aplikasi merupakan sebuah perencanaan aplikasi yang akan dikembangkan untuk memenuhi kebutuhan, yang terdiri dari deskripsi daftar kandidat aplikasi yang akan dikembangkan. Kandidat aplikasi tersebut diperoleh dari hubungan entitas data dan proses bisnis yang akan dijelaskan pada arsitektur data. Kandidat aplikasi 
tersebut sebagai alternatif dalam mengakomodasi kebutuhan aplikasi pada proses bisnis.

\section{c. Arsitektur Teknologi}

Arsitektur teknologi, meliputi rancangan topologi jaringan, platform teknologi yang akan dikembangkan. Rancangan tersebut akan mendukung rancangan aplikasi yang akan dibuat

\section{d. Implementasi dan migrasi}

Tahapan ini merupakan tahapan dimana pengimplementasian serta migrasi rancangan yang telah dibuat. Rancangan tersebut diterapkan sesuai dengan rencana implementasi yang telah dibuat. Melalui tahapan implementasi ini, akan dijabarkan skala prioritas dalam implementasi. Serta memberikan estimasi pelaksaanaan implementasi arsitektur enterprise. Dan selanjutnya akan dilakukan kesimpulan perencanaan yang akan tertuang dalam blueprint.

\section{METODE PENELITIAN}

\subsection{Pengumpulan data}

Pengumpulkan data dengan observasi pada proses manajamen anggaran dan keuangan dengan tujuan untuk memperoleh data proses bisnis kegiatan manajemen anggaran dan belanja. Melakukan mewawancara dengan pihak yang terlibat, untuk memperoleh data yang dapat dipertanggung jawabkan dan data yang akurat. Data dari hasil wawancara menjadi acuan dalam proses perancangan blueprint sistem informasi anggaran yang meliputi profil Perguruan Tinggi, Proses bisnis yang telah ada di Perguruan Tinggi, Infrastruktur teknologi dan sistem informasi yang ada di Perguruan Tinggi. Melakukan kajian pustaka dari buku referensi, jurnal penelitian, melakukan telaah dokumen bisnis serta mencari sumber lain yang berkaitan dengan perancangan blueprint sistem informasi menggunakan metodologi Enterprise Architecture Planinng.

1. Inisialisasi perencanaan

Mendefinisikan ruang lingkup enterprise, visi, misi, tujuan, menentukan metodologi, serta menentukan tim pengembang sistem.

2. Mendefinisikan enterprise saat ini

Membuat Pemodelan proses bisnis yang sudah berjalan, melakukan identifikasi dan mendefinisikan fungsi bisnis, mendefinisikan teknologi yang dipergunakan dan sistem yang saat ini berjalan.

3. Merencanakan enterprise masa depan

Melakukan perencanaan enterprise untuk masa depan, memodelkan proses bisnis masa depan, merencanakan sistem dan teknologi yang tepat untuk masa depan.

\subsection{Alur Penelitian}

Alur dari penelitian ini mendeskripsikan tahapan tahapan penelitian dari awal sampai dengan selesai. Seperti pada Gambar 1. 


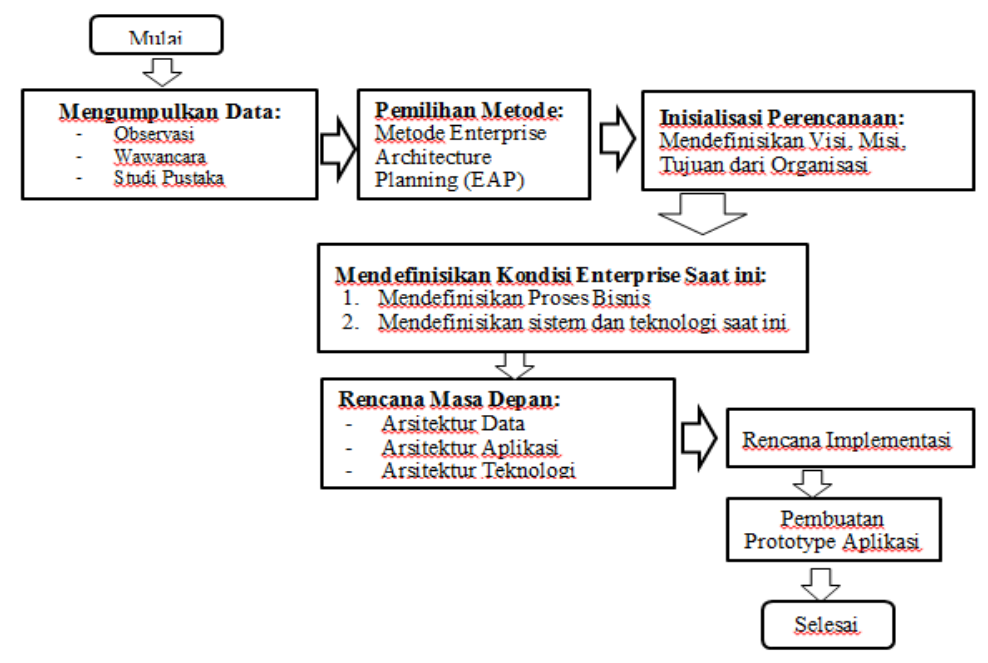

Gambar 1. Alur Penelitian

\section{HASIL DAN PEMBAHASAN \\ 4.1 Pengumpulan Data}

Metode Pengamatan (Observasi) dengan mengamati secara langsung proses dalam manajamen anggaran dan keuangan di Perguruan Tinggi. Serta pengumpulan data terhadap sistem dan teknologi yang dimiliki Perguruan Tinggi. Tahapan pengamatan ini dilakukan guna mendapatkan gambaran tentang proses bisnis yang ada di Perguruan Tinggi khususnya bagian manajemen anggaran dan belanja.

Wawancara dilakukan dengan mewawancarai pihak atau unit instansi yang terlibat, sehingga data yang diperoleh dapat dipertanggung jawabkan dan lebih akurat. Pihak Perguruan Tinggi yang terkait adalah Wakil Rektor II (bidang Keuangan Sarana Prasarana dan Rumah Tangga), Biro Keuangan, Sarana Prasarana dan Rumah Tangga, Bagian SIM (Sistem Informasi Manajemen). Wawancara dengan Wakil Rektor II (bidang Keuangan Sarana Prasarana dan Rumah Tangga) dan Biro Keuangan, Sarana Prasarana dan Rumah Tangga ini meliputi proses bisnis yang saat ini sudah ada di Perguruan Tinggi. Sedangkan wawancara dengan Bagian SIM (Sistem Informasi Manajemen) meliputi infrastruktur sistem dan teknologi yang ada di Perguruan Tinggi. Materi wawancara meliputi Profil dan sejarah institusi, Proses manajemen anggaran dan belanja di institusi, Sistem informasi dan infrastruktur teknologi yang ada di institusi

Studi Pustaka dengan mencari referensi dari literatur penelitian yang sudah ada tentang blueprint system informasi dengan menggunakan metodologi Enterprise Architecture Planning.

\subsection{Pemilihan Metodologi EAP}

Berdasarkan tahapan pengumpulan data dan inisiasi perencanaan. Penelitian ini memilih metodologi Enterprise Architecture Planning sebagai metode peneliti dalam mengembangkan blueprint sistem informasi dikarenakan metodologi ini memiliki alur yang berurutan dan lengkap dalam mengembangkan sistem informasi. Mulai dari tahapan awal perencanaan sampai dengan tahapan implementasi dan migrasi.

\subsection{Inisialisasi Perencanaan}

a. Menentukan Ruang Lingkup Enterprise

Blueprint yang disusun merupakan Blueprint Sistem Informasi Manajemen anggaran dan belanja yang mana akan memberikan gambaran tentang proses Manajemen Anggaran Keuangan dan Sarana Prasarana yang ada di Perguruan Tinggi. 
b. Mendefinisikan Visi Misi

Dari visi misi dari Perguruan Tinggi maka dirumuskan sebagai berikut "Penyelenggaran organisasi yang sehat dengan didukung sistem pendidikan tinggi berdasarkan perkembangan IPTEK"

c. Menentukan Metodologi

Blueprint Sistem Informasi Manajemen anggaran dan belanja disusun dengan menggunakan metodologi Enterprise Architecture Planning karena dalam metodologi ini menyelaraskan kebutuhan teknologi informasi dengan visi misi enterprise sehingga akan diperoleh tujuan akhir yang terarah dan juga tepat

d. Menentukan Tim Pengembangan

Tim penyusun dan pengembang dipilih berdasarkan kapasitas masing masing sebagai tim yang ahli sesuai bidangnya. Tim ini dibagi menjadi tim Eksekutif dan Penanggung Jawab, tim IT, tim Keuangan, dan tim pendukung.

\subsection{Mendefinisikan Kondisi Enterprise Saat Ini}

\section{Pemodelan Proses Bisnis}

Digunakan untuk menjadikan dasar dalam menetapkan rencana arsitektur. Pengidentifikasian pemodelan proses bisnis meliputi identifikasi struktur organisasi, definisi fungsi bisnis, relasi proses bisnis terhadap unit kerja. Hasil permodelan proses bisnis didapatkan rantai nilai (value chain), Matriks relasi proses bisnis dengan unit kerja.

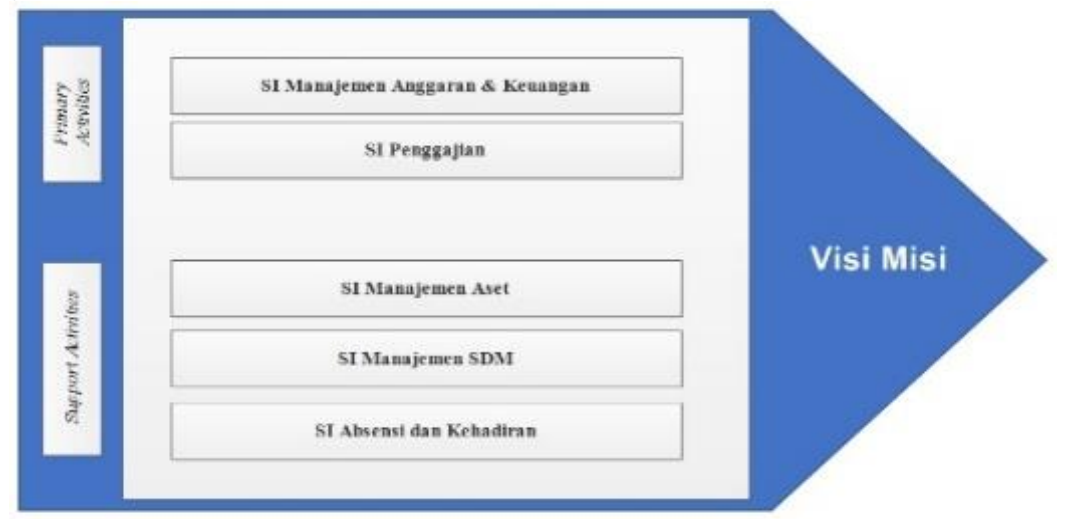

Gambar 2 Value Chain Sistem Manajemen anggaran dan belanja

2. Kondisi Teknologi dan Sistem saat ini

Tahapan dalam tinjauan kondisi enterprise saat ini adalah pengamatan terhadap teknologi dan sistem yang dimiliki dan digunakan oleh enterprise.

3. Katalog Sumber Daya Informasi (Information Resource Catalog atau IRC)

Pengamatan terhadap sistem dan teknologi saat ini yang ada di enterprise, akan memberikan gambaran mengenai kondisi teknologi dan sistem informasi yang saat ini dimiliki, yang nantinya akan menghasilkan katalog sumber daya informasi (Information Resourche Catalog atau IRC). Katalog tersebut akan mendeskripsikan secara singkat sistem informasi yang digunakan.

\subsection{Kondisi Enterprise di Masa Depan}

a. Inisialisasi Perancanaan Enterprise Masa Depan

Perencanaan enterprise masa depan dalam proses manajemen anggaran dan belanja di Perguruan Tinggi ini melibatkan beberapa proses bisnis di Perguruan Tinggi yang digambarkan dalam skema pada gambar 3. 


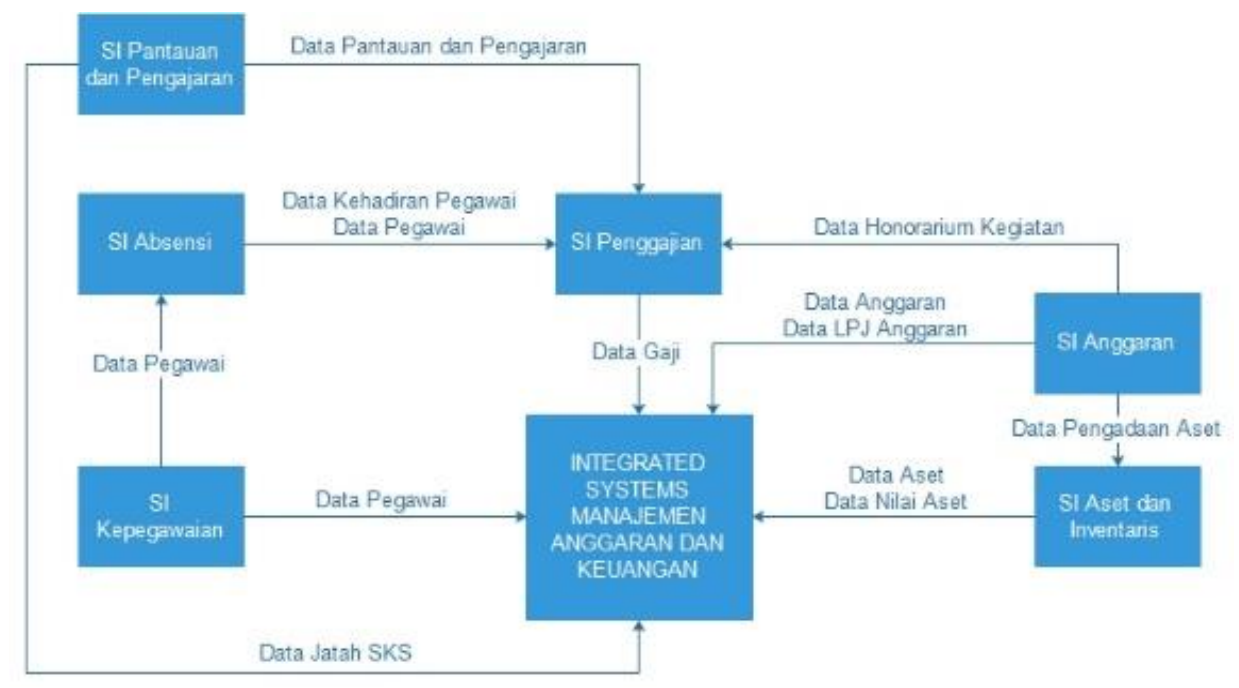

Gambar 3. Skema Sistem Manajemen anggaran dan belanja Terintegrasi

b. Membuat Pemodelan Proses Bisnis

Berikut ini adalah salah satu pemodelan proses bisnis yang ada di Perguruan Tinggi yaitu proses penggajian.

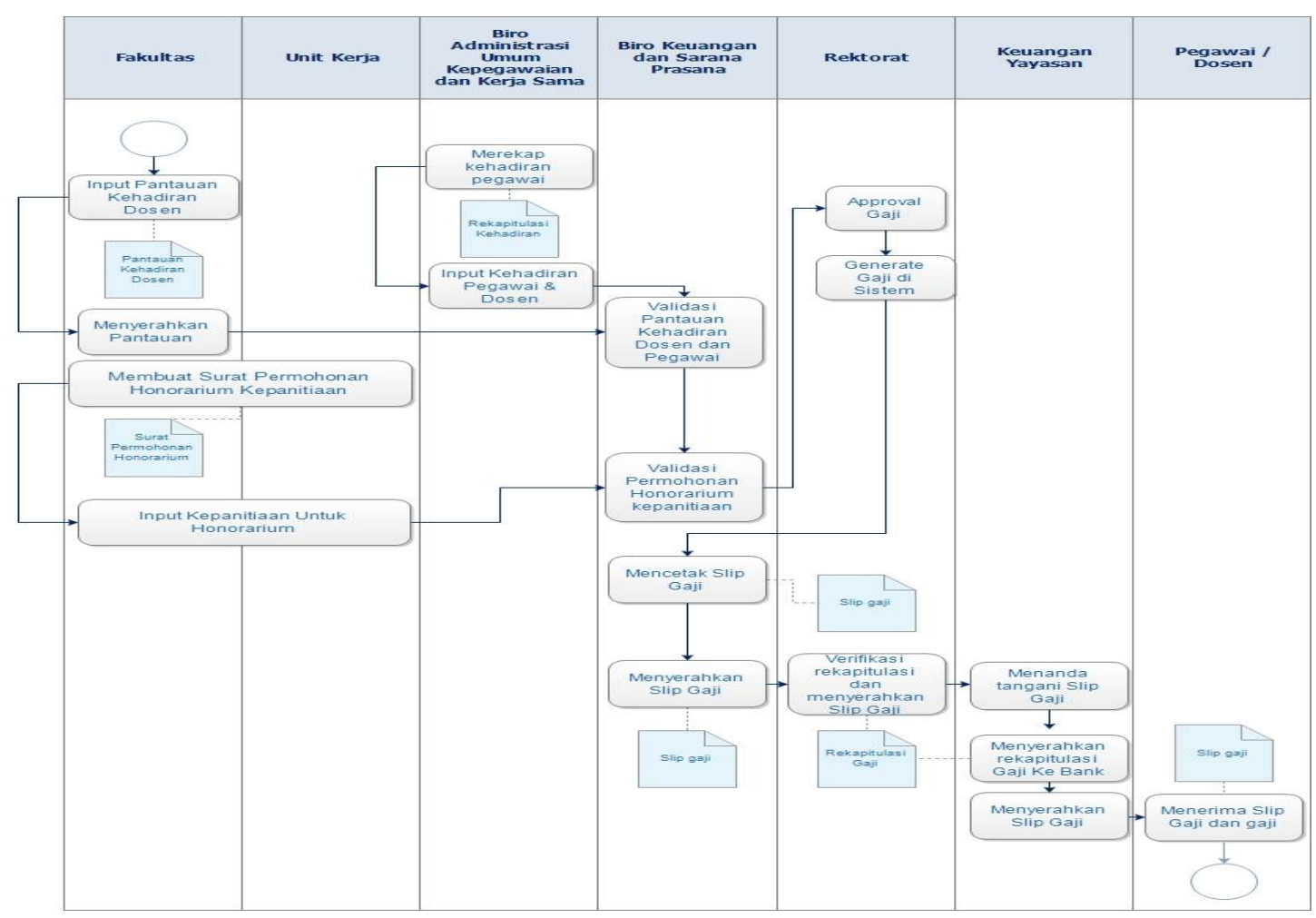

Gambar 4. Permodelan Bisnis Penggajian

c. Sistem dan Teknologi Yang Akan Dipergunakan

Pengembangan sistem informasi manajemen anggaran dan belanja, khususnya proses penggajian dibangun dengan platform web dan akan terkoneksi melalui jaringan internet maupun intranet.

d. Arsitektur Data

Pengembangan blueprint manajemen anggaran dan belanja dengan memperhatikan kebutuhan data dan informasi, sehingga diperlukan daftar entitas yang terlibat. Seperti terlihat pada Tabel 1 . 
Tabel 1 Entitas Bisnis dan Data yang terlibat

\begin{tabular}{|c|c|}
\hline Entitas Bisnis & Entitas Data \\
\hline \multirow{4}{*}{ Entitas Anggaran } & Entitas Komponen Anggaran \\
\hline & Entitas Usulan Anggaran \\
\hline & Entitas Penggunaan Anggaran \\
\hline & Entitas Pelaporan Anggaran \\
\hline \multirow{5}{*}{ Entitas Gaji } & Entitas Komponen Gaji \\
\hline & Entitas Periode Gaji \\
\hline & Entitas Usulan Gaji \\
\hline & Entitas Penggajian \\
\hline & Entitas Pelaporan Gaji \\
\hline \multirow{8}{*}{ Entitas Aset } & Entitas Kategori Aset \\
\hline & Entitas Jenis Aset \\
\hline & Entitas Ruang \\
\hline & Entitas Pengadaan Aset \\
\hline & Entitas Aset dan Inventaris \\
\hline & Entitas Pelaporan Aset \\
\hline & Entitas Penghapusan Aset \\
\hline & Entitas Mutasi Aset \\
\hline \multirow{6}{*}{ Entitas Pegawai } & Entitas Pegawai \\
\hline & Entitas Jabatan Fungsional \\
\hline & Entitas Jabatan Struktural \\
\hline & Entitas Unit Kerja \\
\hline & Entitas Pangkat dan Golongan \\
\hline & Entitas Sertifikasi dan Pengembangan \\
\hline \multirow[t]{4}{*}{ Entitas Absensi } & Entitas Absen \\
\hline & Entitas Jadwal Kerja \\
\hline & Entitas Reward Absensi \\
\hline & Entitas Punishment Absensi \\
\hline \multirow{3}{*}{ Entitas Pantauan dan Pengajaran } & Entitas Dosen \\
\hline & Entitas Jatah SKS \\
\hline & Entitas Pantauan \\
\hline
\end{tabular}

e. Membuat Arsitektur Aplikasi

Arsitektur aplikasi dibuat dengan mempertimbangkan kebutuhan setiap proses. Untuk merencanakan arsitektur aplikasi ada 3 tahapan, yaitu :

1) Kandidat aplikasi yang diusulkan dapat dilihat pada Tabel 2.

Tabel 2 Usulan Kandidat Aplikasi

\begin{tabular}{|c|c|c|}
\hline Fungsi Bisnis & Aplikasi / Sistem Informasi & Status \\
\hline \multirow[t]{2}{*}{ Anggaran } & Aplikasi Pengajuan Anggaran & $\wedge$ \\
\hline & Aplikasi Pertanggungjawaban Anggaran & $\wedge$ \\
\hline \multirow[t]{4}{*}{ Penggajian } & Aplikasi Pengajuan Gaji & $\wedge$ \\
\hline & Aplikasi Pengajuan Kehadiran & $\wedge$ \\
\hline & Aplikasi Rekapitulasi Gaji & $*$ \\
\hline & Aplikasi Laporan dan Cetak Gaji & * \\
\hline \multirow[t]{3}{*}{ Aset } & Aplikasi Permohonan Pengadaan Aset & $\wedge$ \\
\hline & Aplikasi Mutasi dan Pemusnahan Aset & $\wedge$ \\
\hline & Aplikasi Laporan Aset & $\wedge$ \\
\hline \multirow[t]{3}{*}{ Kepegawaian } & Aplikasi Data Pegawai & \# \\
\hline & Aplikasi Pemutakhiran Data Pegawai & $*$ \\
\hline & Aplikasi Laporan Data Pegawai & $*$ \\
\hline \multirow{5}{*}{ Absensi } & Aplikasi Penarikan Data Absensi & \# \\
\hline & Aplikasi Real time absensi kehadiran & $\sim$ \\
\hline & Aplikasi Permohonan Cuti / Tidak Masuk Kerja & $\wedge$ \\
\hline & Aplikasi Rekapitulasi Absen & \# \\
\hline & Aplikasi Pelaporan Absensi & \# \\
\hline \multirow{2}{*}{$\begin{array}{l}\text { Pantauan dan } \\
\text { Pengajaran }\end{array}$} & Aplikasi Pembuatan SK Pengampu Mata Kuliah & $\wedge$ \\
\hline & Aplikasi Pantauan Kehadiran Dosen & $\wedge$ \\
\hline
\end{tabular}




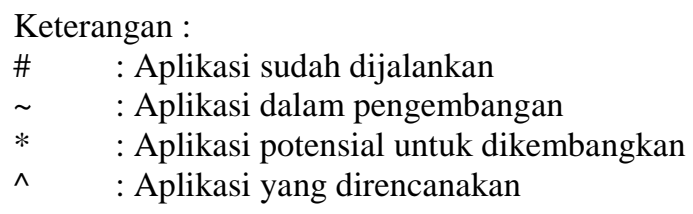

2) Pemetaan kandidat aplikasi dengan fungsi bisnis direpresentasikan pada Tabel 3. Tabel 3 Pemetaan Aplikasi dengan Fungsi Bisnis

\begin{tabular}{|c|c|c|c|c|c|c|}
\hline Aplikasi & 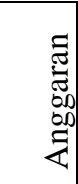 & ف & 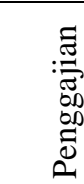 & 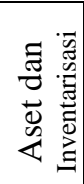 & 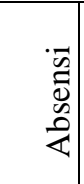 & 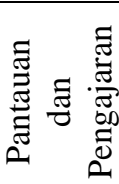 \\
\hline SI Anggaran & $\sqrt{ }$ & & $\sqrt{ }$ & $\sqrt{ }$ & & \\
\hline SI Pegawai & $\sqrt{ }$ & $\sqrt{ }$ & $\sqrt{ }$ & & $\sqrt{ }$ & $\sqrt{ }$ \\
\hline SI Penggajian & $\sqrt{ }$ & $\sqrt{ }$ & $\sqrt{ }$ & & $\sqrt{ }$ & $\sqrt{ }$ \\
\hline SI Aset & $\sqrt{ }$ & & & $\sqrt{ }$ & & \\
\hline SI Absensi & & $\sqrt{ }$ & $\sqrt{ }$ & & $\sqrt{ }$ & \\
\hline SI Pantauan dan Pengajaran & & $\sqrt{ }$ & $\sqrt{ }$ & & & $\sqrt{ }$ \\
\hline
\end{tabular}

3) Analisis Gap Arsitektur Aplikasi direpresentasikan pada Tabel 4 Tabel 4. Analisis Gap

\begin{tabular}{|c|c|c|}
\hline Aplikasi saat ini & $\begin{array}{l}\text { Rencana } \\
\text { Aplikasi }\end{array}$ & Analisa Gap \\
\hline SI Anggaran & SI Anggaran & $\begin{array}{l}(A D D) \text { Komponen Anggaran } \\
(A D D) \text { Kategori Anggaran } \\
(A D D) \text { Unit Kerja } \\
(A D D) \text { Pengajuan Anggaran } \\
(A D D) \text { Verifikasi dan Validasi Anggaran } \\
(A D D) \text { Pencairan Anggaran } \\
(A D D) \text { Laporan Pertanggungjawaban Anggaran } \\
(A D D) \text { Laporan Penyerapan Anggaran }\end{array}$ \\
\hline SI Penggajian & SI Penggajian & $\begin{array}{l}\text { (REPLACE) Master Data } \\
(\text { REPLACE }) \text { Komponen Gaji } \\
(\text { REPLACE }) \text { Kepanitiaan } \\
(\boldsymbol{R E P L A C E}) \text { Kehadiran } \\
(\boldsymbol{R E P L A C E}) \text { Rekapitulasi Gaji } \\
(\boldsymbol{R E P L A C E}) \text { Cetak Slip Gaji } \\
(\boldsymbol{R E P L A C C E}) \text { Laporan Gaji }\end{array}$ \\
\hline SI Aset & SI Aset & $\begin{array}{l}(A D D) \text { Jenis dan Kategori Aset } \\
(A D D) \text { Permohonan dan Pengadaan Aset } \\
(A D D) \text { Pendataan Aset } \\
(A D D) \text { Mutasi Aset } \\
(A D D) \text { Laporan Aset }\end{array}$ \\
\hline SI Kepegawaian & SI Kepegawaian & $\begin{array}{l}(\text { RETAIN) Pendataan Pegawai } \\
(\text { REPLACE) Riwayat Pangkat dan Golongan } \\
(\text { REPLACE) Riwayat Jabatan Struktural } \\
(\text { REPLACE) Riwayat Jabatan Fungsional } \\
(\text { REPLACE) Pemutakhiran Data Pegawai } \\
(\text { REPLACE) Riwayat Pelatihan } \\
(\text { REPLACE) Riwayat Pendidikan } \\
(\text { REPLACE) Laporan Pegawai }\end{array}$ \\
\hline SI Absensi & SI Absensi & $\begin{array}{l}\text { (ADD) Pengajuan Izin Tidak Masuk Kerja } \\
(A D D) \text { Rekapitulasi Absensi Real Time }\end{array}$ \\
\hline $\begin{array}{l}\text { SI Pantauan dan } \\
\text { Pengajaran }\end{array}$ & $\begin{array}{l}\text { SI Pantauan dan } \\
\text { Pengajaran }\end{array}$ & $\begin{array}{l}\text { (ADD) Pembuatan SK Pengampu Mata Kuliah } \\
(A D D) \text { Pantauan Kehadiran Dosen }\end{array}$ \\
\hline
\end{tabular}


Hasil Analisa Gap direpresentasikan pada Tabel 5.

Tabel 5. Hasil Analisa Gap

\begin{tabular}{|l|l|l|}
\hline Analisa Gap & Jumlah & Prosentase \\
\hline Add & 17 & $53,125 \%$ \\
\hline Retain & 1 & $3,125 \%$ \\
\hline Replace & 14 & $43,75 \%$ \\
\hline Remove & 0 & $0 \%$ \\
\hline Jumlah & 32 & $100 \%$ \\
\hline
\end{tabular}

4) Arsitektur Teknologi

Pengembangan arsitektur teknologi sangat mendukung seluruh proses bisnis yang ada di Perguruan Tinggi. Dalam pengembangan arsitektur teknologi ini akan terbagi menjadi :

a. Internet dan Arsitektur Jaringan

Untuk infrastruktur jaringan dibuatlah mapping jaringan untuk kabel dan juga nirkabel. Untuk menunjang proses yang ada di Perguruan Tinggi, maka diperlukan arsitektur jaringan yang menjadi sarana integrasi antar sistem serta unit. Jaringan kabel dan nirkabel akan digambarkan pada peta jaringan Gambar 5.

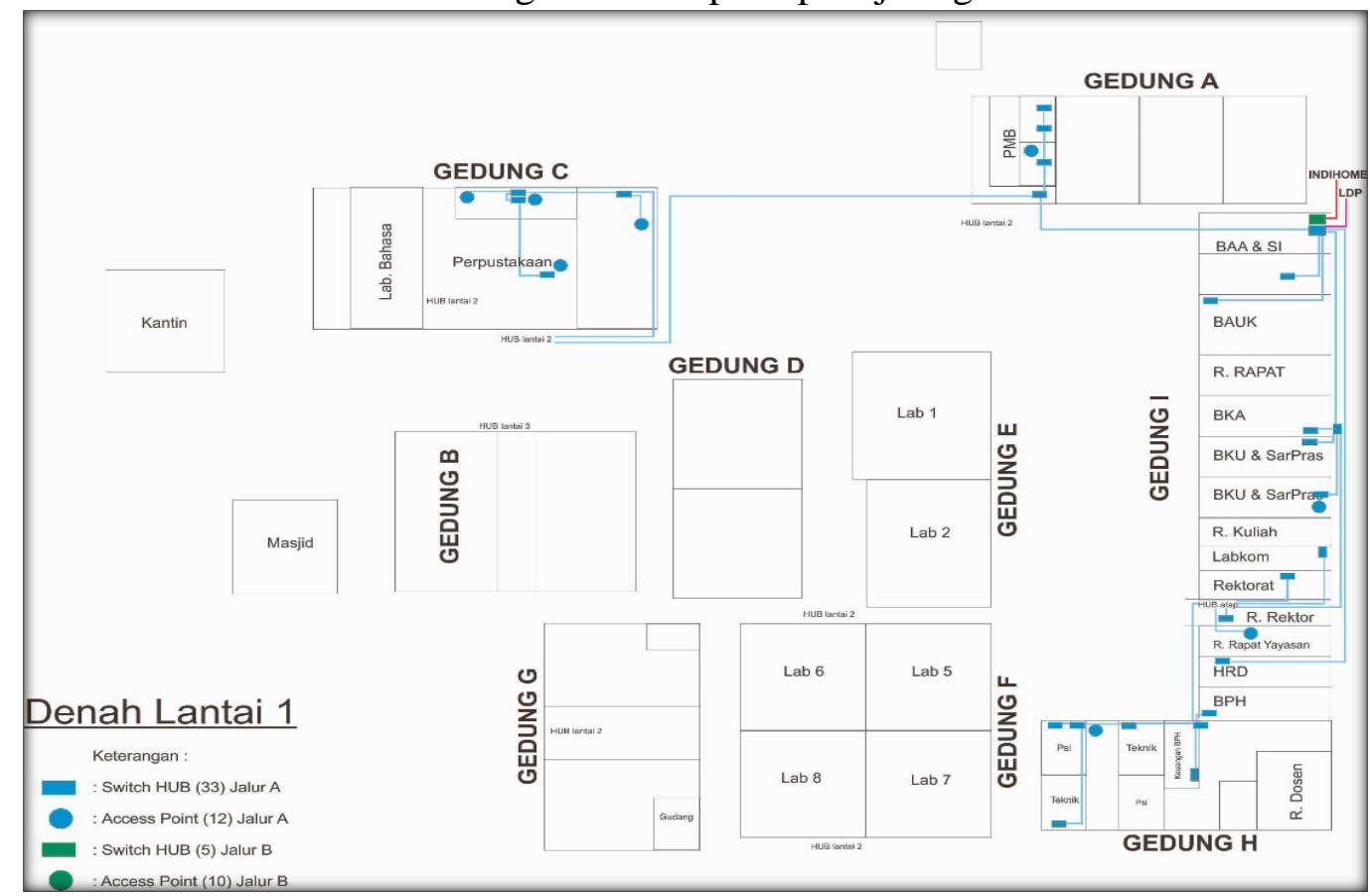

Gambar 5 Peta Jaringan Kabel dan Nirkabel

b. Server dan Perangkat Personal Computer (PC)

Perangkat teknologi seperti server dan PC sangatlah dibutuhkan. Dalam perencanaan teknologi ini djabarkan kebutuhan server dan PC. Untuk server perlu ditambahkan 1 buah server dengan spesifikasi minimal sebagai berikut:

a) Processor Intel Xeon Generasi Terbaru

b) RAM 32 Gigabyte

c) Storage dengan kapasitas 4 Terabyte

Untuk Personal Computer (PC), untuk yang berada di setiap unit kerja diharapkan sudah memiliki spesifikasi minimal :

a) Processor Intel Core i3

b) RAM 4 Gigabyte

c) Storage dengan kapasitas 500 Gigabyte 
Spesifikasi server dan Personal Computer (PC) diatas adalah spesifikasi minimal yang harus dimiliki dalam pengadaan kedepannya. Untuk jangka 5 tahun, spesifikasi server sudah cukup mumpuni untuk kebutuhan akses data yang mana hanya diakses oleh seluruh unit kerja. Serta untuk Personal Computer (PC) masih sangat mumpuni untuk proses kegiatan di unit kerja karena hanya digunakan untuk pengolahan data sederhana dan kegiatan administrasi saja, tidak untuk rendering, maupun pengolahan bigdata. Namun untuk beberapa bagian yang membutuhkan spesifikasi untuk rendering, editing video, maupun bagian khusus yang membutuhkan spesifikasi tinggi menyesuaikan sesuai dengan kebutuhan.

c. Hardware

Kebutuhan hardware penunjang, seperti printer, mesin absensi, scanner. Seluruh perangkat tersebut untuk menunjang kegiatan dalam proses bisnis yang ada di Perguruan Tinggi.

Proses bisnis pengelolaan absensi, perlu adanya penambahan mesin presensi dalam 5 tahun diperlukan penambahan, dari 2 mesin presensi existing menjadi 4 mesin, dengan rincian 2 existing, 1 dipasang pada titik lokasi tambahan, serta 1 lagi untuk cadangan.

5) Implementasi dan Migrasi

Untuk tahapan implementasi, akan dibuatkan roadmap rencana pengembangan, seperti terlihat pada Tabel 5.

Tabel 5. Roadmap Pengembangan

\begin{tabular}{|c|c|c|c|c|c|c|c|c|c|c|c|c|c|c|c|c|c|c|c|c|c|c|c|c|c|c|}
\hline \multicolumn{27}{|c|}{ ROADMAP PENGENBANGAN SISTEM INFORIIASI MANAJENIEN ANGGARAN DAN KEUANGAN } \\
\hline \multirow{3}{*}{ Fungsi Bisnis } & \multirow{3}{*}{ Aplikasi Sistem Informasi } & \multirow{2}{*}{\multicolumn{4}{|c|}{2019}} & \multirow{2}{*}{\multicolumn{10}{|c|}{2020}} & & & & & & & & & & & \\
\hline & & & & & & & & & & & & & & & & \multicolumn{11}{|c|}{2021} \\
\hline & & Aug $\mid$ Sep & Okt & Nov $D$ & Des & $\operatorname{Tan}$ & \begin{tabular}{|l|l|l}
$\mathrm{Feb}$ & $\mathrm{M}$
\end{tabular} & Mar A $_{\text {A }}$ & \begin{tabular}{l|l} 
Apr & Mei \\
\end{tabular} & Lei Jun & Jul & Aug : & g Sep & okt & Nov Des & s $\operatorname{Tan}$ & Feb $1 \mathrm{~A}$ & Mar & Apr & Mei $\mathrm{J}$ & & Jul & Aug Sep & Okt & & Des \\
\hline Kepegawaian & Aplikasi data pegawai & & & & & & & & & & & & & & & & & & & & & & & & & \\
\hline Absensi & Aplikasi Penarikan data Absensi & & & & & & & & & & & & & & & & & & & & & & & & & \\
\hline Absensi & Aplikasi Rekapitulasi Absen & & & & & & & & & & & & & & & & & & & & & & & & & \\
\hline Absensi & Aplikasi Pelaporan Absen & & & & & & & & & & & & & & & & & & & & & & & & & \\
\hline Absensi & Aplikasi Real time Absensi kehadiran & & & & & & & & & & & & & & & & & & & & & & & & & \\
\hline Penggajian & Aplikasi Rekapitulasi Gaji & & & & & & & & & & & & & & & & & & & & & & & & & \\
\hline Penggajian & Aplikasi Laporan dan Cetak Gaji & & & & & & & & & & & & & & & & & & & & & & & & & \\
\hline Kepegawaian & Aplikasi Pemutakhiran Data Pegawai & & & & & & & & & & & & & & & & & & & & & & & & & \\
\hline Kepegawaian & Aplikasi Pelaporan Data Pegawai & & & & & & & & & & & & & & & & & & & & & & & & & \\
\hline Pantauan dan Pengajaran & Aplikasi Pembuatan SK Pengampu Mata Kuliah & & & & & & & & & & & & & & & & & & & & & & & & & \\
\hline Pantauan dan Pengajaran & Aplikasi Pantauan Kehadiran Dosen & & & & & & & & & & & & & & & & & & & & & & & & & \\
\hline Absensi & Aplikasi Permohonan Cuti/ Tidak Masuk Kejja & & & & & & & & & & & & & & & & & & & & & & & & & \\
\hline Anggaran & Aplikasi Pengajuan Anggaran & & & & & & & & & & & & & & & & & & & & & & & & & \\
\hline Anggaran & Aplikasi Pertanggungjawaban Anggaran & & & & & & & & & & & & & & & & & & & & & & & & & \\
\hline Penggajian & Aplikasi Pengajuan Gaji & & & & & & & & & & & & & & & & & & & & & & & & & \\
\hline Penggajian & Aplikasi Pengajuan Kehadiran & & & & & & & & & & & & & & & & & & & & & & & & & \\
\hline Aset & Aplikasi Permohonan Pengadaan Aset & & & & & & & & & & & & & & & & & & & & & & & & & \\
\hline Aset & Aplikasi Inventarisasi Aset & & & & & & & & & & & & & & & & & & & & & & & & & \\
\hline Aset & Aplikasi Mutasi dan Pemusnahan Aset & & & & & & & & & & & & & & & & & & & & & & 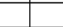 & & & \\
\hline Aset & Aplikasi Laporan Aset & & & & & & & & & & & & & & & & & & & & & & & & & \\
\hline
\end{tabular}

\section{PENUTUP}

\subsection{Kesimpulan}

1. Blueprint sistem informasi manajemen anggaran dan belanja telah disusun, Blueprint tersebut meliputi beberapa proses bisnis yaitu proses bisnis manajemen anggaran, penggajian, manajemen aset, manajemen SDM, absensi dan kehadiran. Blueprint yang disusun menggunakan metode Enterprise Architecture Planning (EAP) terdiri dari arsitektur data, arsitektur aplikasi, arsitektur teknologi serta rencana implementasi dan migrasi. Analisis GAP untuk arsitektur sistem informasi yang digunakan dibandingkan dengan Arsitektur yang disusun masih ditemukan Gap, yaitu masih ada entitas yang harus ditambahkan (add), dipertahankan (retain), diganti (replace) serta dihilangkan (remove), dengan rincian Add sebanyak 17 entitas, Retain sebanyak 1 entitas, Replace sebanyak 14 entitas, sedangkan entitas yang perlu dihilangkan (Remove) tidak ada, sehingga total keseluruhan GAP sebesar 32 entitas. Jika diprosentase sebagai berikut Add (53,125\%), Retain (3,125\%), Replace (43,75\%), Remove (0\%). Serta untuk hasil analisis gap arsitektur teknologi Add (28,57\%), Retain (14,29\%), Replace (57,14\%), Remove (0\%). 
2. Pengembangan arsitektur aplikasi Sistem Informasi Penggajian dibuat sebagai salah satu portofolio kandidat arsitektur aplikasi. Sistem informasi penggajian telah terintegrasi dengan sistem informasi manajemen SDM.

\subsection{Saran}

Saran untuk penelitian selanjutnya adalah

1. Blueprint manajemen anggaran dan belanja, dapat dikembangkan lebih detail lagi terhadap perancangan kandidat aplikasi yang telah tercantum di blueprint.

2. Scope integrasi sistem ditambahkan lebih luas lagi, sehingga dapat dikembangkan sistem terintegrasi dengan database terpusat

\section{DAFTAR PUSTAKA}

Ambarsari, N., \& Setyoutami, N. (2014). Perancangan Blueprint Sistem Informasi Menggunakan Metodologi Enterprise Architecture Planning (Eap) Pada Sman 3 Surakarta. Jurnal Rekayasa Sistem Dan Industri, 1(01), 141-143.

Ayu, N., Dewi, N., Sinaga, B. L., \& Rusdianto, E. (2013). ( Studi kasus : Rumah Sakit Umum Daerah ). 2013(semnasIF), 194-201.

Bernard, S. A. (2009). The Importance of Formal Documentation In Enterprise Architectures. Journal of Enterprise Architecture, August, 29-58.

Kurniawan, A. P., \& Chazar, C. (2015). Perencanaan Cetak Biru Sistem Informasi Terintegrasi Berbasis E2AF dan Metodologi EAP. VII(1), 25-44.

Kurniawan, B. (2011). Enterprise architecture planning sistem informasi pada perguruan tinggi swasta dengan zachman framework. Majalah Ilmiah UNIKOM, 9(1), 21-32. http://jurnal.unikom.ac.id/jurnal/enterprise-architecture.x/volume-91-artikel-3.pdf

Miftahuddin, Y., Ichwan, M., \& Musrini, M. (2013). Penerapan Metode EAP ( Enterprise Architecture. Jurnal Informatika, 4(1).

Surendro, K., Kajian, B., Informasi, S., Informatika, T., \& Arsitektur, P. (2007). Pemanfaatan Enterprise Architecture Planning Untuk Perencanaan Strategis Sistem Informasi. Jurnal Informatika, 8(1), 9-9. https://doi.org/10.9744/informatika.8.1.pp.19 